\title{
Jefferson
}

Thomas Jefferson University

The Medicine Forum

2016

\section{A Tribute to our Nurses}

Anusha Govind, MD

Thomas Jefferson University, anusha.govind@jefferson.edu

Follow this and additional works at: https://jdc.jefferson.edu/tmf

Part of the Internal Medicine Commons, and the Nursing Commons

Let us know how access to this document benefits you

\section{Recommended Citation}

Govind, MD, Anusha (2016) "A Tribute to our Nurses," The Medicine Forum: Vol. 17, Article 22.

DOI: https://doi.org/10.29046/TMF.017.1.022

Available at: https://jdc.jefferson.edu/tmf/vol17/iss1/22

This Article is brought to you for free and open access by the Jefferson Digital Commons. The Jefferson Digital Commons is a service of Thomas Jefferson University's Center for Teaching and Learning (CTL). The Commons is a showcase for Jefferson books and journals, peer-reviewed scholarly publications, unique historical collections from the University archives, and teaching tools. The Jefferson Digital Commons allows researchers and interested readers anywhere in the world to learn about and keep up to date with Jefferson scholarship. This article has been accepted for inclusion in The Medicine Forum by an authorized administrator of the Jefferson Digital Commons. For more information, please contact: JeffersonDigitalCommons@jefferson.edu. 


\title{
A Tribute to Our Nurses
}

\author{
Anusha Govind, MD
}

I turned faint and weary as the page came through

"Your patients heart rate is one hundred eighty"

My legs shook as I ran up the stairs

Thoughts racing a mile a minute, hoping someone more knowledgeable might be there first

As I turned a corner, color draining from my face Then I spot my savior, the nurse, holding a syringe filled with the medication

I knew now my patient and I were in good hands.

As I had a conversation with my patient and her family Her medication pumps went off, the bed alarm blared, the television roared loudly in the background

We were trying to answer her serious questions in somber, hushed tones

Trying to convey our understanding of her disease processes

Removing every distraction, her nurse was there To turn off the pump, help the patient up in bed, pause the television remote

Allowing us all to focus on the health of our patient Another patient needs labs every four hours to make sure his body doesn't reject his medications

Veins thin and thready, rolling and scarred

He winces in pain as he was stuck for the fourth time tonight

Ultrasound, tighter tourniquets, smaller needles

When all he really needed was a nurse's sensitive touch.

One finger on the target vessel, holding it taut

Finally, labs were drawn.

Three more hours into the night, a patient complains of more pain

We had already given him large doses of analgesics

We told the patient once, knowing he'll ask again, against his better judgment

"No more, not for another few hours"

A seemingly simple answer from the house staff

While behind the scenes, a nurse was truly alleviating pain by adjusting his bed, placing a heating pad, laying a

comforting hand on where it hurts

Compassion, a virtue each nurse is blessed with.
As the night comes to an end,

Sleepy eyed house staff wander, CODE BLUE, CODE BLUE

Suddenly everyone's running

Nurses there first, compressions already begun.

I frantically wonder, what exactly happened? What do I do next?

The nursing team already with the crash cart in hand Suggest epinephrine.

The code quickly turns from chaos to an organized rhythm

Her pulse restarted. Nurses calling loved ones.

Compliment the team on a job well done.

The early hours dawn, and the 4 am interns start their rounds

Interns turn pale as the patient yells about his pain and all the distractions over night

Only the intern, often the receiver of frustration, as the day starts

Tears pouring down, trying to comfort

Who runs in to save the morning,

But the nurse. Easing the patient and intern alike

A twinkle in her eye, as the nurse knows year after year, her jobs gets harder on July first.

That beloved last page of the night.

"Patient is vomiting. I've cleaned them, changed them, and restarted their fluids. Maybe they need something for nausea?"

Everything the patient really needs has already been done.

As I reflect on the night, There's little I could have done well without my nurses.

"Sure, zofran. Thank you...For everything" 